\title{
PERSEPSI MASYARAKAT TERHADAP DAMPAK SOSIAL EKONOMI DARI PERUSAHAAN PERKEBUNAN KELAPA SAWIT PT. HENRISON INTI PERSADA KABUPATEN SORONG PAPUA BARAT
}

\author{
Jakson Arnold Klasibin \\ Caroline B. D. Pakasi \\ Celcius Talumingan
}

\begin{abstract}
This study aims to determine the public perception of the socio-economic impact of oil palm plantation company PT. Henrison Inti Persada in Sorong district of West Papua. This research was conducted from February to April 2017. The data used are primary data and secondary data. This research was conducted with in-depth interview technique with 30 (thirty) respondents in this case the people living around this company operate and also use observation and literature study. The data obtained will be analyzed using descriptive analysis which each answer is tested and tested using Likert scale. The results of this study indicate that the index of public perceptions on the socio-economic impact of oil palm plantation companies PT. Henrison Inti Persada is at $81.11 \%$ and is relatively high, meaning the existence of oil palm plantation company PT. Henrison Inti Persada has a social and economic impact that must be increased again to the community, because every indicator has a positive impact as well as the negative impact that must be viewed by the oil palm plantation company PT. Henrison Inti Persada.
\end{abstract}

Keywords: people's perception, socio-economic impact, Sorong regency, West Papua.

\begin{abstract}
ABSTRAK
Penelitian ini bertujuan untuk mengetahui persepsi masyarakat terhadap dampak sosial ekonomi dari perusahaan perkebunan kelapa sawit PT. Henrison Inti Persada di Kabupaten Sorong Papua Barat. Penelitian ini dilaksanakan pada bulan Februari hingga April 2017. Data yang digunakan adalah data primer dan data sekunder. Penelitian ini dilakukan dengan teknik wawancara mendalam dengan 30 (tiga puluh) orang responden dalam hal ini masyarakat yang tinggal di sekitar perusahaan ini beroperasi dan juga menggunakan pengamatan serta studi kepustakaan. Data yang diperoleh akan dianalisis menggunakan analisis deskriptif yang setiap jawabannya diangkakan dan diuji dengan menggunakan skala likert. Hasil penelitian ini menunjukkan bahwa angka indeks persepsi masyarakat terhadap dampak sosial ekonomi dari perusahaan perkebunan kelapa sawit PT. Henrison Inti Persada berada pada titik $81,11 \%$ dan tergolong tinggi, artinya keberadaan perusahaan perkebunan kelapa sawit PT. Henrison Inti Persada memiliki dampak sosial dan ekonomi yang harus di tingkatkan lagi kepada masyarakat, karena setiap indikator ada dampak positif dan juga dampak negatif yang harus di lihat oleh perusahaan perkebunan kelapa sawit PT. Henrison Inti Persada.
\end{abstract}

Kata kunci: persepsi masyarakat, dampak sosial ekonomi, PT. Henrison Inti Persada, Kabupaten Sorong, Papua Barat. 


\section{PENDAHULUAN}

\section{Latar Belakang}

Perusahaan dan masyarakat yang bermukim di sekitarnya merupakan dua komponen yang saling mempengaruhi. Keberadaan perusahaan tidak dapat dipungkiri memiliki dampak terhadap masyarakat sekitarnya. Dampak tersebut dapat berupa dampak positif seperti antara lain penciptaan lapangan pekerjaan dan peningkatan ekonomi, maupun dampak negatif seperti antara lain penurunan kualitas lingkungan dan kesehatan masyarakat.

Masyarakat memiliki cara pandang tersendiri mengenai perusahaan. Cara masyarakat sekitar memandang perusahaan tersebut dapat diartikan sebagai persepsi. Leavitt (2000), menyatakan bahwa persepsi (perception) adalah pandangan atau pengertian, yaitu bagaimana seseorang memandang atau mengartikan sesuatu. Menurut Ambadar (2008), paradigma perusahaan yang hanya berorientasi memperoleh laba (profit) sebesar-besarnya sudah mulai bergeser dan mulai berupaya memberikan dampak positif keberadaannya bagi kesejahteraan masyarakat sekitar.

Tanggung jawab sosial perusahaan merupakan salah satu upaya perusahaan untuk membina hubungan baik dengan masyarakat. Beberapa manfaat yang dapat dirasakan oleh perusahaan melalui kegiatan tanggung jawab perusahaan sebagai upaya pengembangan masyarakat berdasarkan hasil penelitian Herlin (2008), adalah untuk mempublikasikan keberadaannya sehingga hubungan yang baik dengan stakeholder (dalam hal ini masyarakat) dapat terwujud dan membina hubungan baik dengan masyarakat sehingga tidak pernah terjadi konflik.

Upaya perusahaan untuk menjalin hubungan dengan masyarakat lainnya adalah melalui komunikasi publik perusahaan. Menurut Hadi (2001), hubungan perusahaan dengan komunitas merupakan suatu tindakan yang harus dilakukan perusahaan untuk memelihara dan membina hubungan dengan lingkungannya melalui komunikasi yang saling menguntungkan.

Perusahaan merupakan suatu unit kegiatan tempat kerja sama faktor-faktor produksi (alam, tenaga kerja, modal dan keahlian pengusaha) yang menghasilkan barang atau jasa untuk memenuhi kebutuhan masyarakat atau melayani kepentingan masyarakat, dengan tujuan memperoleh laba atau keuntungan. Penggolongan perusahaan dapat dibagi menjadi dua yaitu perusahaan menurut badan hukumnya dan perusahaan menurut operasinya. Perusahaan menurut badan hukumnya ada lima yaitu perusahaan perseorangan, firma, persekutuan komanditer, perseroan terbatas dan koperasi. Sedangkan perusahaan menurut operasinya ada tiga yaitu perusahaan jasa, perusahaan dagang dan perusahaan industri (manufaktur).

Semua perusahaan mempunyai persediaan yang merupakan investasi terbesar dalam aktiva lancar, baik pada perusahaan jasa, dagang maupun manufaktur. Pada perusahaan jasa tidak semuanya mempunyai persediaan, hanya sebagian perusahaan jasa saja yang mempunyai persediaan seperti perusahaan jasa transportasi. Pada perusahaan dagang, persediaan yang terdiri dari berbagai macam dan jenis yang hanya dikenal satu klasifikasi persediaan yang disebut dengan persediaan barang dagangan, dimana persediaan tersebut adalah milik perusahaan dan siap untuk dijual kepada konsumen. Sedangkan pada perusahaan manufaktur, tidak semua persediaan siap untuk dijual. Berbeda dengan persediaan barang dagangan, persediaan pada perusahaan manufaktur digolongkan menjadi tiga bagian yaitu persediaan bahan baku, persediaan barang dalam proses dan persediaan barang jadi.

PT Henrison Inti Persada bagian dari perusahaan Global Supply Chain Management, adalah perusahaan perkebunan kelapa sawit yang berlokasi di Kabupaten Sorong Papua Barat. PT. Henrison Inti Persada sudah memiliki perkebunan panen, areal pengembangan baru dan areal rehabilitasi. PT. Henrison Inti Persada yang sudah mulai beroperasi sejak 2004 di Distrik Klamono, Kabupaten Sorong, PT. Henrison Inti Persada menyadari pentingnya memahami kebutuhan sosial ekonomi masyarakat sekitar kebun. Terlebih ketika di lapangan seringkali dijumpai perbedaan pandangan dan penafsiran atas peran dan kedudukan masing-masing. Perusahaan melalui program kepedulian kepada masyarakat, misalnya, telah melakukan berbagai program bantuan mulai dari fisik, ekonomi sampai pendidikan. Di sisi lain, masyarakat lokal sepertinya menaruh harapan lebih pada perusahaan dengan seringkali menunjukan klaim dan permintaan bantuan.

PT. Henrison Inti Persada untuk memahami kondisi sosial ekonomi dalam rangka menigkatkan hubungan sosial ekonomi yang lebih baik dengan masyarakat setempat, perusahaan bermaksud membuat kajian sosial ekonomi di wilayah distrik Klamono. Fokus kajian adalah 
untuk "Mengkaji dan memberikan penilaian atas kehadiran atau keberadaan perusahaan perkebunan dan perubahan sosial ekonomi yang dialami masyarakat, sebagai bahan untuk menyusun strategi pengembangan industri kelapa sawit dengan mempertimbangkan potensi dan kemajuan masyarakat lokal Papua".

Berdasarkan uraian tersebut, keberadaan PT. Henrison Inti Persada sebagai salah satu perusahaan perkebunan kelapa sawit yang berada di Kabupaten Sorong, Provinsi Papua Barat, tentu memiliki pengaruh terhadap kehidupan sosial ekonomi masyarakat disekitar lokasi perkebunan PT. Henrison Inti Persada tersebut. Perubahan yang terjadi akibat keberadaan perkebunan kelapa sawit akan menimbulkan hal-hal positif atau sebaliknya, akan menimbulkan hal-hal negatif yang justru merugikan masyarakat sekitarnya. Hal ini mendorong saya mengangkat dan mengajukan penelitian yang berjudul "persepsi masyarakat terhadap dampak sosial ekonomi dari perusahaan perkebunan kelapa sawit PT. Henrison Inti Persada di Kabupaten Sorong Papua Barat”.

\section{Rumusan Masalah}

Berdasarkan latar belakang yang telah diuraikankan tersebut, maka yang menjadi rumusan masalah dari penelitian ini adalah: Bagaimana persepsi masyarakat terhadap dampak sosial ekonomi dari perusahaan perkebunan kelapa sawit PT. Henrison Inti Persada di Kabupaten Sorong Papua Barat.

\section{Tujuan Penelitian}

Berdasarkan rumusan masalah tersebut, maka tujuan dari penilitian ini yaitu untuk: Mengetahui persepsi masyarakat terhadap dampak sosial ekonomi dari perusahaan perkebunan kelapa sawit PT. Henrison Inti Persada di Kabupaten Sorong Papua Barat.

\section{Manfaat Penelitian}

Penelitian ini diharapkan bermanfaat bagi:

\section{Perusahaan}

Penelitian ini diharapkan dapat menambah pengetahuan dan pemahaman bagi perusahaan mengenai bagaimana persepsi masyarakat terhadap dampak sosial ekonomi dari perusahaan perkebunan kelapa sawit PT. Henrison Inti Persada di Kabupaten Sorong Papua Barat.
2. Masyarakat

Penelitian ini diharapkan dapat memberikan masukan bagi perusahaan dalam menjalankan kegiatannya di wilayah tersebut dan dapat menambah pengetahuan masyarakat mengenai bagaimana persepsi masyarakat terhadap dampak sosial ekonomi dari Perusahaan Perkebunan Kelapa Sawit PT. Henrison Inti Persada di Kabupaten Sorong Papua Barat.

3. Penulis

Menambah pengetahuan dan sebagai alat ukur kemampuan teori yang diperoleh dari perkuliahan maupun dari literatur-literatur, serta diharapkan memenuhi syarat sebagai suatu karya ilmiah untuk menyelesaikan studi di Universitas Sam Ratulangi Fakultas Pertanian, Jurusan Sosial Ekonomi, Program Studi Agribisnis.

\section{METODOLOGI PENELITIAN}

\section{Waktu dan Tempat Penelitian}

Penelitian ini berlangsung selama 3 bulan sejak bulan Februari hingga bulan April 2017. Tempat penelitian di kampung Malalilis, Gisim Darat, Maladofok Kabupaten Sorong Papua Barat.

\section{Jenis dan Metode Pengumpulan Data}

Data yang digunakan dalam penelitan ini adalah data primer dan sekunder.

1. Data primer

Data primer merupakan data yang di peroleh dari sumber pertama atau sumber asli (langsung dari informan), misalnya dari individu atau perorangan dan yang lainnya merupakan sumber utama data penelitian.

2. Data Sekunder

Data sekunder merupakan data yang diperoleh dari sumber kedua atau bukan dari sumber aslinya. Data sekunder ini biasa berbentuk data yang tersaji dalam bentuk tabel, grafik, internet dan lain sebagainya. Sumber data sekunder dapat berasal dari peneliti sebelumnya, lembaga pemerintah, lembaga swasta, dan lain sebagainya.

\section{Metode Pengambilan Sampel}

Pengambilan sampel penelitian ini menggunakan teknik purposive sampling. Teknik ini mencakup orang-orang yang diseleksi atas dasar kriteria-kriteria tertentu, berdasarkan tujuan penelitian. Teknik purposive sampling ini digunakan karena peneliti ingin mendapatkan kedalaman data, (Kriyantono, 2006). 
Objek dalam penelitian ini adalah seluruh penduduk asli suku moi yang telah tinggal sebelum beroperasinya perusahaan kelapa sawit PT. Henrison Inti Persada dan masih tinggal di kampung-kampung dimana perusahaan ini beroperasi tersebut sampai saat ini dan juga penduduk yang datang dari daerah lain, jumlah responden yang akan digunakan dalam penelitian ini adalah 30 responden, 15 untuk orang asli Papua (suku Moi) dan 15 untuk pendatang atau masyarakat dari daerah lain.

\section{Konsepsi dan Pengukuran Variabel} ini adalah:

Variabel yang akan digunakan pada penelitian

1. Identitas Responden

a) Jenis Kelamin: Artinya terdiri dari dua jenis kelamin yaitu pria dan wanita.

b) Usia: Usia dari masa dimana masyarakat itu memiliki usia produktif.

c) Pendidikan: Tingkat latar belakang pendidikan yang ditempuh masyarakat sampai mana (tidak sekolah, SD, SMP, SMA, Diploma, Sarjana).

d) Pekerjaan: Jenis pekerjaan yang dimiliki oleh masyarakat berbeda-beda antaralain: Petani, PNS, Swasta dan Ibu rumah tangga.

2. Dampak dari Perusahaan

a) Sosial

1. Kehadiran pendatang akibat adanya perusahaan merupakan hal yang menganggu kehidupan sosial masyarakat.

2. Pendatang memiliki kesempatan dan peluang yang lebih besar untuk bekerja di perusahaan.

3. Perusahaan memperhatikan masalahmasalah sosial yang terjadi pada masyarakat.

4. Sebelum adanya perusahaan masyarakat melakukan gotong royong dalam membangun fasilitas kampong.

5. Adanya ketersediaan sarana-sarana sosial seperti (tempat ibadah, sekolah, puskesmas dan lain-lain).

b) Ekonomi

1. Banyak tenaga kerja lokal yang di pekerjakan oleh perusahaan.

2. Adanya ketersediaan sarana ekonomi yang dilakukan oleh perusahaan misalnya (pasar, toko, koperasi, warung makan dan lain-lain).

3. Perusahaan memperhatikan kebutuhan ekonomi masyarakat.

4. Peluang usaha yang terbuka semenjak adanya perusahaan merupakan hal yang positif bagi masyarakat.

5. Perusahaan perlu meningkatkan perekonomian masyarakat

Metode Analisis Data
Teknik analisis data yang digunakan dalam penelitian ini adalah analisis deskriptif yang setiap jawabannya diangkakan dan diuji dengan menggunakan skala likert (likert scale). Analisis deskriptif bertujuan untuk memahami dengan lebih baik atau lebih dalam mengenai setiap permasalahan sosial ekonomi dan interaksi manusia dan untuk mendapat jawaban yang lebih dalam mengenai suatu fenomena sosial ekonomi.

Analisis deskriptif berusaha mencari pemecahan masalah dengan menganalisis dari gambaran hubungan sebab akibat dari faktor-faktor tertentu yang berhubungan dengan fenomena dari objek yang diteliti. Skala likert (likert scale) memungkinkan responden untuk mengekspresikan intensitas perasaan mereka lebih luas. Hal ini karena pertanyaan dalam skala likert memiliki jawaban yang berjenjang atau memiliki jawaban yang lebih banyak (Ridwan, 2012 dalam Umboh, 2014). Dalam penelitian ini skala likert digunakan untuk mengukur variabel persepsi masyarakat terhadap dampak sosial ekonomi. Dari variabel tersebut disusun 10 pertanyaan dengan total responden 30 orang. Setiap jawaban dihubungkan dengan bentuk pertanyaan atau dukungan diungkapkan dengan kata-kata yaitu jenjang 1 (tidak setuju), 2 (cukup setuju), 3 (setuju).

Dengan cara perhitungan skor masing-masing pertanyaan:

Jumlah Skor tiap Kritrium = Capaian Skor X Jumlah Responden

Untuk:

$$
\begin{aligned}
& S 3=3 \times 30=90 \\
& S 2=2 \times 30=60 \\
& S 1=1 \times 30=30
\end{aligned}
$$

Jumlah skor ideal untuk setiap pernyataan (skor tertinggi) $=90$

Jumlah skor terendah $=30$

Dengan Interpretasi nilai :
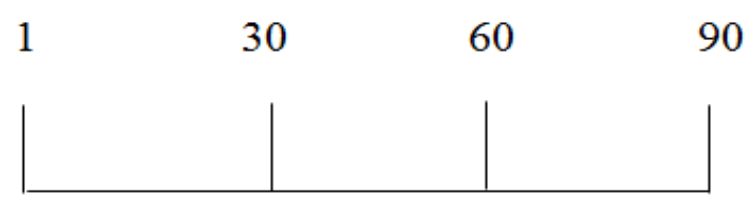

Cara perhitungan skor keseluruhan untuk mengetahui persepsi masyarakat terhadap dampak sosial ekonomi dari perusahaan perkebunan kelapa sawit PT. Henrison Inti Persada.

Jumlah skor seluruh kriterium = capaian jumlah skor X Jumlah Responden X Instrumen Pertanyaan

Untuk:

$$
\mathrm{S} 3=3 \times 30 \times 10=900
$$


$\mathrm{S} 2=2 \times 30 \times 10=600$

$\mathrm{S} 3=1 \times 30 \times 10=300$

Jumlah skor ideal untuk keseluruhan pernyataan $=900$

Jumlah skor terendah $=300$

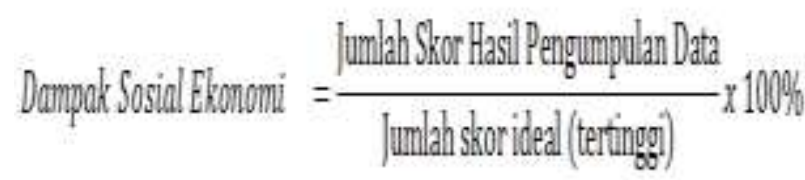

Keterangan Kriteria interpretasi skor persepsi

Dengan Interpretasi Nilai :

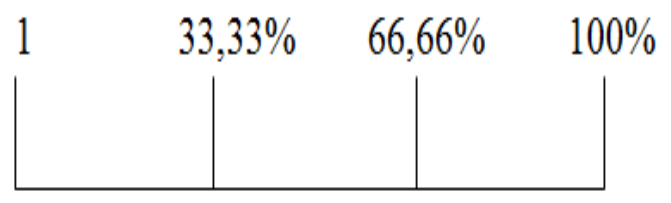

masyarakat terhadap dampak sosial ekonomi:

Angka 0\% - 33,33\% = Rendah

Angka 33,34\% - 66,66\% = Cukup

Angka 66,67\% - 100\% = Tinggi

\section{HASIL DAN PEMBAHASAN}

\section{Gambaran Umum PT. Henrison Inti Persada}

PT. Henrison Inti Persada adalah perusahaan berbentuk perseroan terbatas (PT) dan merupakan perusahaan yang menghasilkan Crude Palm Oil dan Palm Kernel. Terletak di distrik Klamono, Klasafet, Klayili dan Sayosa Kabupaten Sorong, Provinsi Papua Barat, dan perusahaan ini sudah mulai beroperasi dari tahun 2004 sampai saat ini. Secara astronomis terletak pada koordinat $131^{\circ} 21^{`} 59,50^{\prime \prime} \mathrm{BT}-131^{\circ} 49^{\prime} 44,00^{\prime \prime} \mathrm{BT}$ dan $00^{\circ}$ $57^{`} 31,91^{\prime \prime}$ LS $-0,1^{\circ} 12^{`} 26,85^{\prime}$ ” LS yang berjarak $\pm 30 \mathrm{~km}$ dari ibu kota Kabupaten Sorong. Batasbatas lokasi adalah:
a. Sebelah utara berbatasan dengan eks IUPHHK-HA PT. Intimpura Timber Co.
b. Sebelah timur berbatasan dengan eks IUPHHK-HA PT. Intimpura Timber Co.
c. Sebelah selatan berbatasan dengan eks IUPHHK-HA PT. Hasrat Wira Mandiri.
d. Sebelah barat berbatasan dengan eks IUPHHK-HA Hanurata.

Luas areal berdasarkan pelepasan kawasan hutan dari Menteri Kehutanan untuk perkebunan kelapa sawit adalah \pm 32.546 .30$ Ha.

\section{Deskripsi Responden}

Responden yang digunakan dalam penelitian ini merupakan masyarakat yang berdomisili di sekitar perusahaan. Hasil dari penyebaran kuesioner sebanyak 30 responden didapatkan karakteristik responden berdasarkan jenis kelamin, usia, tingkat pendidikan, dan pekerjaan. Berikut dipaparkan hasil dari masing-masing karakteristik responden.

\section{Karakteristik Responden Berdasarkan Jenis Kelamin}

Jenis kelamin responden menjadi salah satu ciri yang dapat membedakan individu, dalam penelitian ini dapat dikelompokkan menjadi dua yaitu: kelompok laki-laki dan kelompok perempuan, yang artinya laki-laki dan perempuan dapat memberikan pandangan yang berbeda terhadap sesuatu hal. Untuk lebih jelasnya adapun rincian responden dapat dijelaskan dalam Tabel 1.

Tabel 1. Karakteristik Responden Berdasarkan Jenis Kelamin

\begin{tabular}{lcc}
\hline Jenis Kelamin & $\begin{array}{c}\text { Jumlah } \\
\text { Responden }\end{array}$ & Persentase \\
\hline Laki-laki & 19 & $63 \%$ \\
Perempuan & 11 & $37 \%$ \\
\hline Total & $\mathbf{3 0}$ & $\mathbf{1 0 0 \%}$ \\
\hline
\end{tabular}

Masyarakat yang menjadi responden dalam penelitian ini lebih banyak laki-laki dengan jumlah 19 orang (63\%), bila dibandingkan dengan jumlah responden perempuan 11 orang (37\%), hal ini dikarenakan populasi dan sampel yang di ambil perkepala keluarga.

\section{Karakteristik Responden Berdasarkan Usia} Responden dibagi menjadi 4 kelompok umur yaitu: 23-32 tahun, 33-42 tahun, 43-52 tahun, dan > 53 tahun. Untuk lebih jelasnya dapat dijelaskan dalam Tabel 2. 


\begin{tabular}{ccc}
\multicolumn{3}{c}{ Tabel 2. Karakteristik Responden Berdasarkan Usia } \\
\hline Usia & Jumlah Responden & Persentase \\
\hline $23-32$ tahun & 10 & $33 \%$ \\
$33-42$ tahun & 7 & $23 \%$ \\
$43-52$ tahun & 11 & $37 \%$ \\
$>53$ tahun & 2 & $7 \%$ \\
\hline Total & $\mathbf{3 0}$ & $\mathbf{1 0 0 \%}$ \\
\hline
\end{tabular}

Tabel 2 menunjukkan responden dibagi dalam 4 kelompok umur yaitu 23-32 tahun dengan persentase 33\% (10 responden), 33-42 tahun tahun dengan persentase $23 \% \quad$ (7 responden), 43 - 52 tahun dengan persentase $37 \%$ (11 responden), dan > 53 tahun dengan persentase $7 \%$ ( 2 responden).

\section{Karakteristik Responden Berdasarkan Tingkat Pendidikan}

Pendidikan meliputi pengajaran keahlian khusus dan juga sesuatu yang tidak dapat dilihat lebih mendalam yaitu pemberian pengetahuan, pertimbangan dan kebijaksanaan. Dengan adanya pendidikan maka dapat memanfaatkan sarana pendidikan yang ada dimana tingkat pendidikan sangat mempengaruhi terhadap kualitas berfikir, sikap dan bertingkah laku masyarakat dalam menjalani kehidupan mereka sehari-hari, yang tentunya juga akan mempengaruhi ranah sosial dan ekonomi dimana mereka melakukan aktifitas. Berikut hasil dari karakteristik responden berdasarkan tingkat pendidikan disajikan pada Tabel 3.

\begin{tabular}{|c|c|c|}
\hline $\begin{array}{r}\text { Tabel 3. Kara } \\
\text { Pend }\end{array}$ & ik Responden Ber & rkan Tingkat \\
\hline $\begin{array}{c}\text { Tingkat } \\
\text { Pendidikan }\end{array}$ & Jumlah Responden & Persentase \\
\hline $\mathrm{SD}$ & 10 & $33 \%$ \\
\hline SLTP & 8 & $27 \%$ \\
\hline SMA & 12 & $40 \%$ \\
\hline Total & 30 & $100 \%$ \\
\hline
\end{tabular}

Tabel 3 menjelaskan bahwa masyarakat yang menjadi responden dalam penelitian ini memiliki tingkat pendidikan yaitu, tamat SD dengan persentase $33 \%$ (10 responden), tamat SLTP dengan persentase $27 \%$ (8 responden), tamat SMA dengan persentase 40\% (12 responden). Hal ini menunjukkan bahwa masih sangat rendahnya tingkat pendidikan masyarakat di daerah tersebut.

\section{Karakteristik Responden Berdasarkan Pekerjaan}

Karakteristik responden selanjutnya adalah berdasarkan jenis pekerjaan. Data ini diperlukan untuk mengetahui berasal dari kalangan pekerjaan apa saja masyarakat yang bekerja di perusahaan bahkan juga yang tinggal dekat dengan perusahaan. Distribusi responden berdasarkan jenis pekerjaan dapat dilihat pada Tabel 4.

\begin{tabular}{|c|c|c|}
\hline Pekerjaan & Jumlah Responden & Persentase \\
\hline Petani & 11 & $37 \%$ \\
\hline Ibu Rumah Tangga & 5 & $17 \%$ \\
\hline PNS & 4 & $13 \%$ \\
\hline Total & 30 & $100 \%$ \\
\hline
\end{tabular}

Tabel 4 menjelaskan bahwa masyarakat yang menjadi responden dalam penelitian ini memiliki pekerjaan yang berbeda-beda yaitu, petani persentase $37 \%$ (11 responden), ibu rumah tangga dengan persentase $17 \%$ (5 responden), Pegawai Negri Sipil (PNS) dengan persentase $13 \%$ (4 responden), swasta 33\% (10 responden). Hal ini menunjukkan bahwa masih banyak masyarakat di daerah tersebut yang memiliki pekerjaan sebagai petani.

\section{Persepsi Masyarakat Terhadap Dampak Sosial Ekonomi dari Perusahaan Perkebunan Kelapa Sawit PT. Henrison Inti Persada Kabupaten Sorong}

Variabel persepsi masyarakat terhadap dampak sosial dan persepsi masyarakat terhadap dampak ekonomi memiliki indikatorindikator persepsi masyarakat terhadap dampak sosial antara lain:

1. Kehadiran pendatang akibat adanya perusahaan merupakan hal yang menganggu kehidupan sosial masyarakat.

2. Pendatang memiliki kesempatan dan peluang yang lebih besar untuk bekerja di perusahaan.

3. Perusahaan memperhatikan masalahmasalah sosial yang terjadi pada masyarakat.

4. Sebelum adanya perusahaan masyarakat melakukan gotong royong dalam membangun fasilitas kampung.

5. Adanya ketersediaan sarana-sarana sosial seperti (Tempat ibadah, Sekolah, Puskesmas dan lain-lain). 
Indikator-indikator dari variabel persepsi masyarakat terhadap dampak ekonomi antara lain:

1. Banyak tenaga kerja lokal yang di pekerjakan oleh perusahaan.

2. Adanya ketersediaan sarana ekonomi yang dilakukan oleh perusahaan misalnya (pasar, toko, koperasi, warung makan dan lain-lain).

3. Perusahaan memperhatikan kebutuhan ekonomi masyarakat.

4. Peluang usaha yang terbuka semenjak adanya perusahaan merupakan hal yang positif bagi masyarakat.

5. Perusahaan perlu meningkatkan perekonomian masyarakat.

Pengukuran terhadap variabel-variabel tersebut dilakukan menggunakan skala ukur Likert dengan jenjang 1 (tidak setuju), 2 (cukup setuju), 3 (setuju).

\section{Persepsi Masyarakat Terhadap Dampak Sosial}

Hasil tabulasi dari variabel persepsi dampak sosial masyarakat, dapat dilihat pada tabel. Penjelasan mengenai persepsi masyarakat terhadap dampak sosial dari perusahaan perkebunan kelapa sawit PT. Henrison Inti Persada serta indikatorindikator pendukung akan dipaparkan.

\section{Kehadiran Pendatang Akibat Adanya Perusahaan Merupakan hal yang Menganggu Kehidupan Sosial Masyarakat}

Tabel 5 menjelaskan tentang indikator kehadiran pendatang akibat adanya perusahaan merupakan hal yang menganggu kehidupan sosial masyarakat.

\begin{tabular}{lcccc}
\multicolumn{6}{l}{ Tabel 5. Banyaknya pendatang (non Orang Asli Papua) } \\
\hline $\begin{array}{l}\text { Alternatif } \\
\text { Jawaban }\end{array}$ & $\begin{array}{c}\text { Alternatif } \\
\text { Skor }\end{array}$ & $\begin{array}{c}\text { Jumlah } \\
\text { Responden } \\
\text { (Orang) }\end{array}$ & $\begin{array}{c}\text { Persentase } \\
\text { Responden }\end{array}$ & $\begin{array}{c}\text { Total } \\
\text { Skor }\end{array}$ \\
\hline Setuju & 3 & 14 & 47 & 42 \\
Cukup Setuju & 2 & 3 & 10 & 6 \\
Tidak Setuju & 1 & 13 & 43 & 13 \\
\hline Total & & $\mathbf{3 0}$ & $\mathbf{1 0 0}$ & $\mathbf{6 1}$ \\
\hline
\end{tabular}

Hasil penelitian ini menunjukan bahwa $47 \%$ responden (14 orang) setuju bahwa kehadiran pendatang akibat adanya perusahaan merupakan hal yang menganggu kehidupan sosial masyarakat, sedangkan, $10 \%$ responden (3 orang) cukup setuju, dan $43 \%$ responden (13 orang) tidak setuju karena mereka merasa kehadiran pendatang tidak menganggu kehidupan sosial masyarakat. Angka indeks mengenai pernyataan nomor 1 yaitu kehadiran pendatang akibat adanya perusahaan merupakan hal yang menganggu kehidupan sosial masyarakat sebesar $67,77 \%$, sehingga interpretasi nilainya tergolong tinggi.
Dampak positif dan negatif dari indikator kehadiran pendatang akibat adanya perusahaan merupakan hal yang menganggu kehidupan sosial masyarakat, dampak positif yaitu masyarakat lokal dapat memahami nilai-nilai sosial dan budaya dari daerah lain, sedangkan dampak negatif yaitu masyarakat lokal merasa tersaingi dengan lapangan pekerjaan yang ada sejak perusahaan kelapa sawit ini berada dan juga masyarakat lokal merasa khawatir akan tergeser atau hilangnya nilai-nilai sosial dan budaya mereka yang sudah ada sejak turun temurun.

\section{Pendatang Memiliki Kesempatan dan Peluang yang Lebih Besar Untuk Bekerja di Perusahaan}

Tabel 6 menjelaskan tentang indikator pendatang memiliki kesempatan dan peluang yang lebih besar untuk bekerja di perusahaan.

\begin{tabular}{lcccc} 
Tabel 6. Pendatang Memiliki Peluang Kerja Lebih Besar \\
\hline $\begin{array}{l}\text { Alternatif } \\
\text { Jawaban }\end{array}$ & $\begin{array}{c}\text { Alternatif } \\
\text { Skor }\end{array}$ & $\begin{array}{c}\text { Jumlah } \\
\text { Responden } \\
\text { (Orang) }\end{array}$ & $\begin{array}{c}\text { Persentase } \\
\text { Responden }\end{array}$ & $\begin{array}{c}\text { Total } \\
\text { Skor }\end{array}$ \\
\hline Setuju & 3 & 26 & 87 & 78 \\
Cukup Setuju & 2 & 3 & 10 & 6 \\
Tidak Setuju & 1 & 1 & 3 & 1 \\
\hline Total & & $\mathbf{3 0}$ & $\mathbf{1 0 0}$ & $\mathbf{8 5}$ \\
\hline
\end{tabular}

Hasil penelitian ini menunjukan bahwa $87 \%$ responden (26 orang) setuju bahwa pendatang memiliki kesempatan dan peluang yang lebih besar untuk bekerja di perusahaan, sedangkan, $10 \%$ responden (3 orang) cukup setuju, dan 3\% responden (1 orang) tidak setuju. Angka indeks mengenai pernyataan nomor 2 yaitu pendatang memiliki kesempatan dan peluang yang lebih besar untuk bekerja di perusahaan sebesar $94,44 \%$, sehingga interpretasi nilainya tergolong tinggi.

Dampak positif dan negatif dari indikator pendatang memiliki kesempatan dan peluang yang lebih besar untuk bekerja di perusahaan. Dampak positif yaitu pendatang bekerja di perusahaan karena mereka merasa semua manusia untuk bertahan hidup harus mempu bekerja dengan baik, sedangkan dampak negatif yaitu masyarakat lokal hanya sedikit orang yang bekerja di perusahaan hal ini di karenakan perusahaan merekrut dan mempekerjakan pendatang lebih banyak, padahal masyarakat lokal menaruh harapan dengan adanya perusahaan ini lebih banyak orang asli Papua yang bekerja di perusahaan kelapa sawit PT. Henrison Inti Persada. 


\section{Perusahaan Memperhatikan Masalah- Masalah Sosial yang Terjadi Pada Masyarakat}

Tabel 7 menjelaskan tentang perusahaan memperhatikan masalah-masalah sosial yang terjadi pada masyarakat.

\begin{tabular}{lcccc} 
Tabel 7. Perusahaan Memperhatikan Masalah-Masalah Sosial & \\
\hline $\begin{array}{l}\text { Alternatif } \\
\text { Jawaban }\end{array}$ & $\begin{array}{c}\text { Alternatif } \\
\text { Skor }\end{array}$ & $\begin{array}{c}\text { Jumlah } \\
\text { Responden } \\
\text { (Orang) }\end{array}$ & $\begin{array}{c}\text { Persentase } \\
\text { Responden }\end{array}$ & $\begin{array}{c}\text { Total } \\
\text { Skor }\end{array}$ \\
\hline Setuju & 3 & 10 & 33 & 30 \\
$\begin{array}{l}\text { Cukup } \\
\text { Setuju }\end{array}$ & 2 & 13 & 43 & 26 \\
Tidak Setuju & 1 & 7 & 23 & 7 \\
\hline Total & & $\mathbf{3 0}$ & $\mathbf{1 0 0}$ & $\mathbf{6 3}$ \\
\hline
\end{tabular}

Hasil penelitian ini menunjukan bahwa $33 \%$ responden (10 orang) setuju bahwa perusahaan memperhatikan masalah-masalah sosial yang terjadi pada masyarakat, sedangkan, $43 \%$ responden (13 orang) cukup setuju dan $23 \%$ responden (7 orang) tidak setuju dengan pernyataan tersebut. Angka indeks mengenai pernyataan nomor 3 yaitu perusahaan memperhatikan masalah-masalah sosial yang terjadi pada masyarakat sebesar $70 \%$, sehingga interpretasi nilainya tergolong tinggi.

Dampak positif dan negatif dari indikator perusahaan memperhatikan masalah-masalah sosial yang terjadi pada masyarakat. Dampak positif yaitu adanya masalah-masalah sosial yang dialami masyarakat perusahaan akan berusaha untuk menyelesaikan masalah-masalah tersebut dengan cara musyawarah bersama-sama masyarakat karena masalah-masalah yang terjadi berkaitan dengan adanya perusahaan, sedangkan dampak negatif yaitu masyarakat seringkali mengkleim bahwa perusahaan tidak memperhatikan masalah-masalah sosial, karena pada dasarnya ada masalah-masalah sosial yang terjadi di masyarakat akibat dari perusahaan dan juga bukan dari perusahaan, sehingga perusahaan hanya memperhatikan masalah-masalah sosial yang terjadi di masyarakat akibat dari perusahaan perkebunan kelapa sawit PT. Henrison Inti Persada.

\section{Sebelum Adanya Perusahaan Masyarakat Melakukan Gotong Royong Dalam Membangun Fasilitas Kampung}

Tabel 8 menjelaskan tentang sebelum adanya perusahaan masyarakat melakukan gotong royong dalam membangun fasilitas kampung.
Tabel 8. Sebelum Adanya Perusahaan Masyarakat Melakukan Gotong Royong Dalam Membangun Fasilitas Kampung

\begin{tabular}{lcccc}
\hline $\begin{array}{l}\text { Alternatif } \\
\text { Jawaban }\end{array}$ & $\begin{array}{c}\text { Alternatif } \\
\text { Skor }\end{array}$ & $\begin{array}{c}\text { Jumlah } \\
\text { Responden } \\
\text { (Orang) }\end{array}$ & $\begin{array}{c}\text { Persentase } \\
\text { Responden }\end{array}$ & $\begin{array}{c}\text { Total } \\
\text { Skor }\end{array}$ \\
\hline Setuju & 3 & 21 & 70 & 63 \\
Cukup Setuju & 2 & 7 & 23 & 14 \\
Tidak Setuju & 1 & 2 & 7 & 2 \\
\hline Total & & $\mathbf{3 0}$ & $\mathbf{1 0 0}$ & $\mathbf{7 9}$ \\
\hline
\end{tabular}

Hasil penelitian ini menunjukan bahwa $70 \%$ responden ( 21 orang) setuju bahwa sebelum adanya perusahaan masyarakat melakukan gotong royong, sedangkan, $23 \%$ responden ( 7 orang) cukup setuju dan $7 \%$ responden ( 2 orang) tidak setuju dengan pernyataan tersebut. Angka indeks mengenai pernyataan nomor 4 yaitu sebelum adanya perusahaan masyarakat melakukan gotong royong dalam membangun fasilitas kampung sebesar $87,77 \%$ sehingga interpretasi nilainya tergolong tinggi.

Dampak positif dan negatif dari indikator sebelum adanya perusahaan masyarakat melakukan gotong royong dalam membangun fasilitas kampung. Dampak positif yaitu tingkat gotong royong yang ada pada masyarakat sebelum adannya perusahaan sangat tinggi dengan cara saling membantu masyarakat dalam membangun rumah dan fasilitas kampung lainnya, sedangkan dampak negatif yaitu setelah adanya perusahaan masyarakat tidak lagi melakukan gotong royong karena mereka menaruh harapan penuh pada perusahaan untuk dapat membuat segala sesuatu dengan lebih mudah tanpa harus melakukan gotong royong.

\section{Adanya Ketersediaan sarana-sarana sosial seperti (Tempat Ibadah, Sekolah, Puskesmas dan lain-lain)}

Tabel 9 menjelaskan tentang saranasarana sosial seperti tempat ibadah, sekolah, puskesmas dan lain-lain.

\begin{tabular}{lcccc} 
Tabel 9. $\begin{array}{c}\text { Ketersediaan Sarana Sosial } \\
\text { Puskesmas dan lain-lain) }\end{array}$ & (Tempat & Ibadah, Sekolah, \\
\hline $\begin{array}{l}\text { Alternatif } \\
\text { Jawaban }\end{array}$ & $\begin{array}{c}\text { Alternatif } \\
\text { Skor }\end{array}$ & $\begin{array}{c}\text { Jumlah } \\
\text { Responden } \\
\text { (Orang) }\end{array}$ & $\begin{array}{c}\text { Persentase } \\
\text { Responden }\end{array}$ & $\begin{array}{c}\text { Total } \\
\text { Skor }\end{array}$ \\
\hline Setuju & 3 & 24 & 80 & 72 \\
Cukup Setuju & 2 & 3 & 10 & 6 \\
Tidak Setuju & 1 & 3 & 10 & 3 \\
\hline Total & & $\mathbf{3 0}$ & $\mathbf{1 0 0}$ & $\mathbf{8 1}$ \\
\hline
\end{tabular}

Hasil penelitian ini menunjukan bahwa $80 \%$ responden (24 orang) setuju bahwa adanya ketersediaan sarana-sarana sosial seperti tempat ibadah, Sekolah, Puskesmas dan lain-lain, sedangkan, $10 \%$ responden (3 orang) cukup setuju dan $10 \%$ responden ( 3 orang) tidak setuju dengan 
pernyataan tersebut. Angka Indeks dari variabel persepsi masyarakat terhadap dampak sosial mengenai pernyataan nomor 5 yaitu ketersediaan sarana sosial (tempat ibadah, sekolah, puskesmas) dan lain-lain sebesar $90 \%$ sehingga interpretasi nilainya tergolong tinggi.

Dampak positif dan negatif dari indikator ketersediaan sarana sosial (tempat ibadah, sekolah, puskesmas dan lain-lain. Dampak positif yaitu sebelum adanya perusahaan tidak adanya ketersediaan sarana-sarana sosial seperti tempat ibadah, sekolah, puskesmas dan lain-lain, setelah adanya perusahaan maka ada juga sarana-sarana sosial seperti tempat ibadah, sekolah, puskesmas dan lain-lain, sedangkan dampak negatif yaitu masih kurangnya ketersediaan sarana-sarana sosial setelah adanya perusahaan dan perlu untuk di tingkatkan oleh perusahaan kepada masyarakat.

\section{Rekapitulasi Variabel Persepsi Masyarakat Terhadap Dampak Sosial}

Hasil perhitungan seluruh variabel persepsi masyarakat terhadap dampak sosial dari perusahaan perkebunan kelapa sawit PT. Henrison Inti Persada Kabupaten Sorong, maka disajikan rekapitulasi sebagai berikut pengukuran variabel persepsi masyarakat terhadap dampak sosial dari perusahaan perkebunan kelapa sawit PT. Henrison Inti Persada.

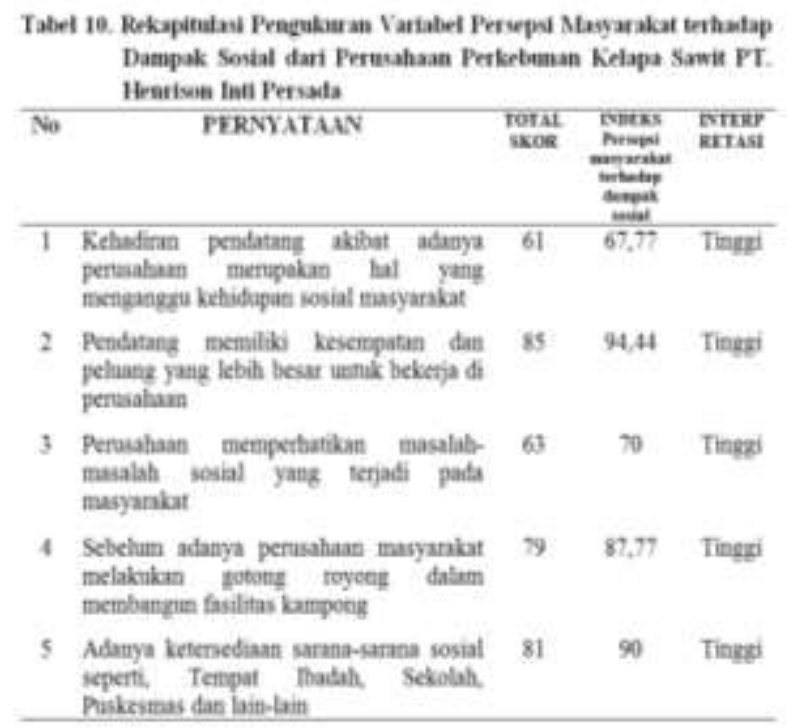

Tabel 10 menunjukan bahwa terdapat 5 indikator pembentuk persepsi dampak sosial masyarakat dimana pernyataan 2 yaitu pendatang memiliki kesempatan dan peluang yang lebih besar untuk bekerja di perusahaan mendapat indeks tertinggi sebesar $94,44 \%$ dengan interpretasi tinggi. Sedangkan pernyataan 5 yaitu adanya ketersediaan sarana-sarana sosial seperti (tempat ibadah, sekolah, puskesmas dan lain-lain) mendapat indeks 90\% dengan interpretasi tinggi. Pernyataan 4 yaitu sebelum adanya perusahaan masyarakat melakukan gotong royong dalam membangun fasilitas kampung mendapat indeks $87,77 \%$ dengan interpretasi tinggi. Pernyataan 3 yaitu perusahaan memperhatikan masalah-masalah sosial yang terjadi pada masyarakat mendapat indeks $70 \%$ dengan interpretasi tinggi. Pernyataan 1 yaitu kehadiran pendatang akibat adanya perusahaan merupakan hal yang menganggu kehidupan sosial masyarakat mendapat indeks $67,77 \%$ dengan interpretasi tinggi, semuanya mendapat interpretasi tinggi karena diatas $66,66 \%$

\section{Persepsi Masyarakat Terhadap Dampak Ekonomi}

Hasil tabulasi atas variabel persepsi masyarakat terhadap dampak ekonomi dapat dilihat pada Tabel. Penjelasan mengenai persepsi masyarakat terhadap dampak ekonomi pada perusahaan perkebunan kelapa sawit PT. Henrison Inti Persada serta indikator-indikator pendukung akan dipaparkan.

\section{Banyak Tenaga Kerja Lokal yang di Pekerjakan Oleh Perusahaan}

Tabel 11 menjelaskan tentang banyaknya tenaga kerja lokal yang di pekerjakan oleh perusahaan.

\begin{tabular}{lcccc}
\multicolumn{5}{l}{ Tabel 11. Banyak tenaga kerja lokal yang bekerja di perusahaan } \\
\hline $\begin{array}{l}\text { Alternatif } \\
\text { Jawaban }\end{array}$ & $\begin{array}{c}\text { Alternatif } \\
\text { Skor }\end{array}$ & $\begin{array}{c}\text { Jumlah } \\
\text { Responden } \\
\text { (Orang) }\end{array}$ & $\begin{array}{c}\text { Persentase } \\
\text { Responden }\end{array}$ & $\begin{array}{c}\text { Total } \\
\text { Skor }\end{array}$ \\
\hline Setuju & 3 & 16 & 53 & 48 \\
Cukup Setuju & 2 & 11 & 37 & 22 \\
Tidak Setuju & 1 & 3 & 10 & 3 \\
\hline Total & & $\mathbf{3 0}$ & $\mathbf{1 0 0}$ & $\mathbf{7 3}$ \\
\hline
\end{tabular}

Hasil penelitian ini menunjukan bahwa $53 \%$ responden (16 orang) setuju bahwa banyak tenaga kerja lokal yang di pekerjakan oleh perusahaan, sedangkan, $37 \%$ responden (11 orang) cukup setuju dan $10 \%$ responden (3 orang) tidak setuju dengan pernyataan tersebut. Angka Indeks dari variabel persepsi masyarakat terhadap dampak ekonomi mengenai pernyataan nomor 1 yaitu banyak tenaga kerja lokal yang di pekerjakan oleh perusahaan sebesar $81,11 \%$ sehingga interpretasi nilainya tergolong tinggi.

Dampak positif dan negatif dari indikator banyak tenaga kerja lokal yang di pekerjakan oleh perusahaan. Dampak positif yaitu masyarakat menyadari bahwa ada juga tenaga kerja lokal yang 
bekerja di perusahaan meskipun tidak sebanding dengan tenaga kerja non lokal yang datang dari daerah lain. Sedangkan dampak negatif yaitu masyarakat melihat bahwa tidak terlalu banyak tenaga kerja lokal yang bekerja di perusahaan hal ini membuat masyarakat lokal merasa tersaingi akan lapangan pekerjaan.

Adanya Ketersediaan Sarana Ekonomi yang dilakukan Oleh Perusahaan misalnya (Pasar, Toko, Koperasi, Warung Makan dan lain-lain)

Tabel 12 menjelaskan tentang adanya ketersediaan sarana ekonomi yang dilakukan oleh perusahaan misalnya (pasar, toko, koperasi, warung makan dan lain-lain).

\begin{tabular}{lcccc} 
Tabel 12. Adanya Sarana Ekonomi Misalnya & (Pasar, Toko, Koperasi, \\
Warung Makan Dan Lain-Lain) & & \\
\hline $\begin{array}{l}\text { Alternatif } \\
\text { Jawaban }\end{array}$ & $\begin{array}{c}\text { Alternatif } \\
\text { Skor }\end{array}$ & $\begin{array}{c}\text { Jumlah } \\
\text { Responden } \\
\text { (Orang) }\end{array}$ & $\begin{array}{c}\text { Persentase } \\
\text { Responden }\end{array}$ & $\begin{array}{c}\text { Total } \\
\text { Skor }\end{array}$ \\
\hline Setuju & 3 & 18 & 60 & 54 \\
Cukup Setuju & 2 & 10 & 33 & 20 \\
Tidak Setuju & 1 & 2 & 7 & 2 \\
\hline Total & & $\mathbf{3 0}$ & $\mathbf{1 0 0}$ & $\mathbf{7 6}$ \\
\hline
\end{tabular}

Hasil penelitian ini menunjukan bahwa $60 \%$ responden (18 orang) setuju bahwa adanya ketersediaan sarana ekonomi yang dilakukan oleh perusahaan misalnya, pasar, toko, koperasi, warung makan, dan lain-lain, sedangkan, 33\% responden (10 orang) cukup setuju dan 7\% responden (2 orang) tidak setuju dengan pernyataan tersebut. Angka Indeks dari variabel persepsi masyarakat terhadap dampak ekonomi mengenai pernyataan nomor 2 yaitu adanya ketersediaan sarana ekonomi yang dilakukan oleh perusahaan misalnya pasar, toko, koperasi, warung makan dan lain-lain sebesar $84,44 \%$ sehingga interpretasi nilainya tergolong tinggi.

Dampak positif dan negatif dari indikator adanya sarana ekonomi (misalnya pasar, toko, koperasi, warung makan dan lain-lain). Dampak positif yaitu memang dengan adanya perusahaan maka terdapat juga sarana ekonomi untuk masyarakat, salah satu sarana ekonomi yang ada yaitu koperasi hal ini membuat masyarakat dapat berbelanja dan juga menabung di koperasi tersebut. Sedangkan dampak negatif yaitu masyarakat melihat masih kurangnya sarana ekonomi yang ada akibat dari adanya perusahaan perkebunan kelapa sawit PT. Henrison Inti Persada.

\section{Perusahaan Memperhatikan Kebutuhan Ekonomi Masyarakat}

Tabel 13 menjelaskan tentang perusahaan memperhatikan kebutuhan ekonomi masyarakat.

\begin{tabular}{lcccc} 
Tabel 13. & $\begin{array}{c}\text { Perusahaan } \\
\text { Masyarakat }\end{array}$ & Memperhatikan & Kebutuhan & Ekonomi \\
\hline $\begin{array}{l}\text { Alternatif } \\
\text { Jawaban }\end{array}$ & $\begin{array}{c}\text { Alternatif } \\
\text { Skor }\end{array}$ & $\begin{array}{c}\text { Jumlah } \\
\text { Responden } \\
\text { (Orang) }\end{array}$ & $\begin{array}{c}\text { Persentase } \\
\text { Responden }\end{array}$ & $\begin{array}{c}\text { Total } \\
\text { Skor }\end{array}$ \\
\hline Setuju & 3 & 14 & 47 & 42 \\
Cukup Setuju & 2 & 9 & 30 & 18 \\
Tidak Setuju & 1 & 7 & 23 & 7 \\
\hline Total & & $\mathbf{3 0}$ & $\mathbf{1 0 0}$ & $\mathbf{6 7}$ \\
\hline
\end{tabular}

Hasil penelitian ini menunjukan bahwa $47 \%$ responden (14 orang) setuju bahwa perusahaan memperhatikan kebutuhan masyarakat sekitar, sedangkan, $30 \%$ responden (9 orang) cukup setuju dan $23 \%$ responden ( 7 orang) tidak setuju dengan pernyataan tersebut. Angka Indeks dari variabel persepsi masyarakat terhadap dampak ekonomi mengenai pernyataan nomor 3 yaitu perusahaan memperhatikan kebutuhan ekonomi masyarakat sebesar 74,44\% sehingga interpretasi nilainya tergolong tinggi.

Dampak positif dan negatif dari indikator perusahaan memperhatikan kebutuhan ekonomi masyarakat. Dampak positif yaitu masyarakat menyadari bahwa selama perusahaan ini beroperasi ada kebutuhan-kebutuhan masyarakat yang di perhatikan salah satunya yaitu kebutuhan ekonomi masyarakat, dengan cara memberikan peluang usaha kepada masyarakat. Dampak nagatif yaitu masyarakat merasa bahwa perusahaan belum sepenuhnya memperhatikan kebutuhan ekonomi masyarakat, karena perusahaan lebih fokus kepada pemilik hak wilayah sehingga masyarakat yang bukan pemilik hak wilayah mereka merasa bahwa perusahaan belum sepenuhnya memperhatikan kebutuhan ekonomi masyarakat.

Peluang Usaha yang Terbuka Semenjak
Kehadiran Perusahaan merupakan hal yang
positif bagi masyarakat
Tabel 14 menjelaskan tentang peluang usaha yang terbuka semenjak kehadiran perusahaan merupakan hal yang positif bagi masyarakat. 


\begin{tabular}{lcccc}
\hline \hline Tabel 14. Peluang & usaha terbuka sejak adanya perusahaan & \\
\hline $\begin{array}{l}\text { Alternatif } \\
\text { Jawaban }\end{array}$ & $\begin{array}{c}\text { Alternatif } \\
\text { Skor }\end{array}$ & $\begin{array}{c}\text { Jumlah } \\
\text { Responden } \\
\text { (Orang) }\end{array}$ & $\begin{array}{c}\text { Persentase } \\
\text { Responden }\end{array}$ & $\begin{array}{c}\text { Total } \\
\text { Skor }\end{array}$ \\
\hline Setuju & 3 & 13 & 43 & 39 \\
Cukup Setuju & 2 & 9 & 30 & 18 \\
Tidak Setuju & 1 & 8 & 27 & 8 \\
\hline Total & & $\mathbf{3 0}$ & $\mathbf{1 0 0}$ & $\mathbf{6 5}$ \\
\hline
\end{tabular}

Hasil penelitian ini menunjukan bahwa $43 \%$ responden (13 orang) setuju bahwa perusahaan memperhatikan kebutuhan masyarakat sekitar, sedangkan, 30\% responden (9 orang) cukup setuju dan $27 \%$ responden ( 8 orang) tidak setuju dengan pernyataan tersebut. Angka Indeks dari variabel persepsi dampak ekonomi masyarakat mengenai pernyataan nomor 4 yaitu peluang usaha terbuka semenjak adanya perusahaan sebesar $72,22 \%$ sehingga interpretasi nilainya tergolong tinggi.

Dampak positif dan negatif dari indikator peluang usaha yang terbuka semenjak kehadiran perusahaan merupakan hal yang positif bagi masyarakat. Dampak positif yaitu sejak adanya perusahaan masyarakat dapat membuat usaha sendiri misalnya toko. Dampak negatif yaitu bagi masyarakat adanya perusahaan belum sepenuhnya memberikan peluang usaha kepada masyarakat, hal ini terjadi karena peluang usaha yang ada tidak sesuai dengan keinginan dari masyarakat.

\section{Perusahaan Perlu Meningkatkan Perekonomian Masyarakat}

Tabel 15 menjelaskan tentang perusahaan perlu meningkatkan perekonomian masyarakat.

\begin{tabular}{lcccc} 
Tabel 15. Perusahaan Perlu Meningkatkan Perekonomian Masyarakat \\
\hline $\begin{array}{l}\text { Alternatif } \\
\text { Jawaban }\end{array}$ & $\begin{array}{c}\text { Alternatif } \\
\text { Skor }\end{array}$ & $\begin{array}{c}\text { Jumlah } \\
\text { Responden } \\
\text { (Orang) }\end{array}$ & $\begin{array}{c}\text { Persentase } \\
\text { Responden }\end{array}$ & $\begin{array}{c}\text { Total } \\
\text { Skor }\end{array}$ \\
\hline Setuju & 3 & 24 & 80 & 72 \\
Cukup Setuju & 2 & 2 & 7 & 4 \\
Tidak Setuju & 1 & 4 & 13 & 4 \\
\hline Total & & $\mathbf{3 0}$ & $\mathbf{1 0 0}$ & $\mathbf{8 0}$ \\
\hline
\end{tabular}

Hasil penelitian ini menunjukan bahwa $80 \%$ responden (24 orang) setuju bahwa perusahaan perlu meningkatkan perekonomian masyarakat, sedangkan, $7 \%$ responden ( 2 orang) cukup setuju dan $13 \%$ responden (4 orang) tidak setuju dengan pernyataan tersebut. Angka Indeks dari variabel persepsi masyarakat terhadap dampak ekonomi mengenai pernyataan nomor 5 yaitu perusahaan perlu meningkatkan perekonomian masyarakat sebesar $88,88 \%$ sehingga interpretasi nilainya tergolong tinggi.

Dampak positif dan negatif dari indikator perusahaan perlu meningkatkan perekonomian masyarakat. Dampak positif yaitu masyarakat berharap bahwa dengan adanya perusahaan maka perekonomian masyarakat dapat meningkat, karena masyarakat yang awalnya bermata pencaharian sebagai petani beralih pekerjaan menjadi masyarakat industri, hal ini membuat masyarakat memiliki anggapan bahwa petani akan mendapat pendapatan yang lebih jika di bandingkan dengan bekerja di perusahaan. Dampak negatif yaitu sempitnya lahan pertanian bagi masyarakat sehingga tidak dapat membuat kebun bagi masyarakat karena telah dijadikan lahan perkebunan kelapa sawit, hal ini membuat masyarakat mengkleim bahwa perusahaan perlu meningkatkan perekonomian masyarakat

Hasil perhitungan seluruh variabel persepsi masyarakat terhadap dampak ekonomi dari perusahaan perkebunan kelapa sawit PT. Henrison Inti Persada Kabupaten Sorong, maka disajikan rekapitulasi pengukuran variabel persepsi masyarakat terhadap dampak ekonomi dari perusahaan perkebunan kelapa sawit PT. Henrison Inti Persada.

\section{Rekapitulasi Variabel Persepsi Masyarakat Terhadap Dampak Ekonomi}

Hasil perhitungan seluruh variabel persepsi masyarakat terhadap dampak ekonomi dari perusahaan perkebunan kelapa sawit PT. Henrison Inti Persada Kabupaten Sorong, maka disajikan rekapitulasi.

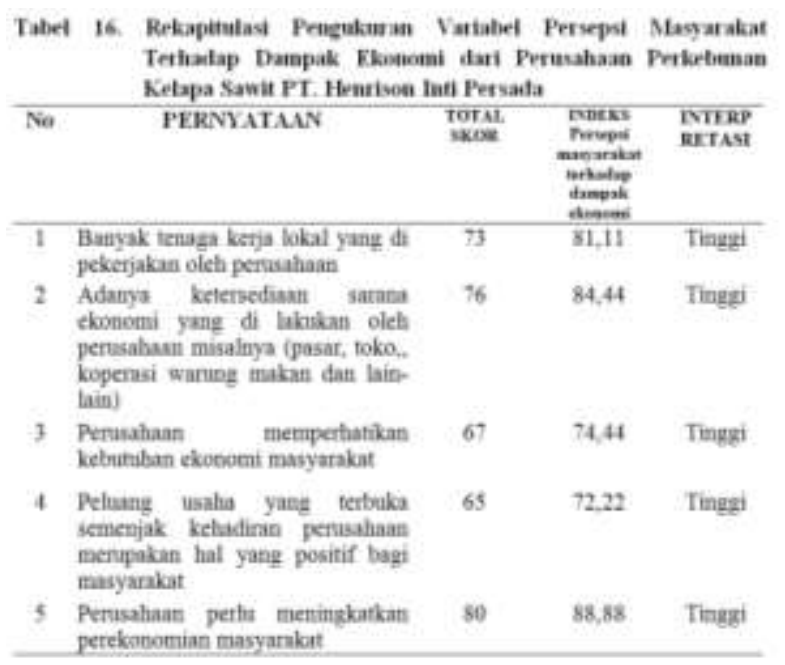

Tabel 16 menunjukan bahwa terdapat 5 indikator pembentuk persepsi masyarakat terhadap dampak ekonomi dimana pernyataan 10 yaitu Perusahaan perlu meningkatkan perekonomian masyarakat, mendapat indeks tertinggi sebesar $88,88 \%$ dengan interpretasi tinggi, sedangkan pernyataan 7 yaitu adanya 
ketersediaan sarana ekonomi yang di lakukan oleh perusahaan misalnya, pasar, toko, koperasi warung makan dan lain-lain mendapat indeks sebesar $84,44 \%$, pernyataan 6 yaitu banyak tenaga kerja lokal yang di pekerjakan oleh perusahaan mendapat indeks sebesar $81,11 \%$, pernyataan 8 yaitu perusahaan memperhatikan kebutuhan ekonomi masyarakat mendapat indeks sebesar $74,44 \%$, pernyataan 9 yaitu peluang usaha yang terbuka semenjak kehadiran perusahaan merupakan hal yang positif bagi masyarakat mendapat indeks 72,22 dan semuanya mendapat interpretasi tinggi karena diatas 66,66\%.

\section{Rekapitulasi Indeks Persepsi Masyarakat Terhadap Dampak Sosial Ekonomi dari Perusahaan Perkebunan Kelapa Sawit PT. Henrison Inti Persada Masing-Masing Variabel dan Interpretasi Hasil}

Penelitian ini untuk mengukur persepsi masyarakat terhadap dampak sosial ekonomi dari perusahaan perkebunan kelapa sawit PT. Henrison Inti Persada Kabupaten Sorong dengan mengambil 10 indikator sebagai tolak ukur dalam penelitian ini, dimana masing-masing terbagi dalam 2 (dua) bagian yaitu variabel persepsi masyarakat terhadap dampak sosial dan persepsi masyarakat terhadap dampak ekonomi.

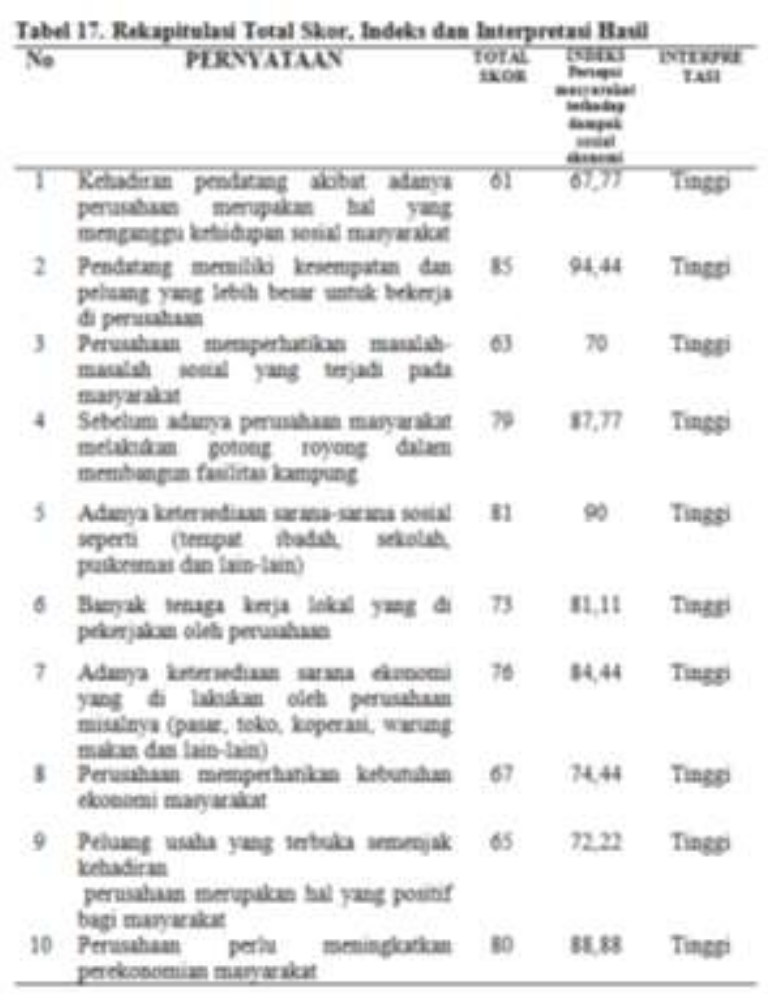

Tabel 17 menunjukan bahwa dari 10 indikator, indikator 1 sampai dengan indikator 10 mendapatkan skor pada indeks yang tergolong tinggi $(66,67-100 \%)$. Hal ini menunjukan bahwa persepsi masyarakat terhadap dampak sosial ekonomi dari perusahaan perkebunan kelapa sawit PT. Henrison Inti Persada tergolong tinggi. Dari indikator 1 sampai 10 terdapat juga dampak positif dan negatif yang telah di uraikan pada tabel setiap indikator.

Hasil untuk mengetahui letak persepsi masyarakat terhadap dampak sosial ekonomi dari perusahaan perkebunan kelapa sawit PT. Henrison Inti Persada, maka perlu dihitung jumlah keseluruhan skor pada setiap kriterium, dimana sesuai hasil penelitian ini skor mencapai 730 pada penelitian ini, jumlah skor ideal (skor tertinggi), yaitu 900 (tinggi) dan jumlah skor terendah yaitu 300 (rendah). Berdasarkan data yang dihimpun dari sebanyak 10 instrumen pernyataan yang diajukan kepada 30 orang responden, maka diperoleh total skor 730, secara persentase, angka indeks persepsi masyarakat terhadap dampak sosial ekonomi dari perusahaan perkebunan kelapa sawit PT. Henrison Inti Persada terletak pada

Persepsi masyarakat terhadap dampak sosial ekonomi

$$
\begin{aligned}
& =\frac{\text { Jumlah skor hasil pengumpulan data }}{\text { Jumlah skor ideal (tertinggi) }} 100 \% \\
& =\frac{730}{900} \times 100 \%=81,11 \%
\end{aligned}
$$

Berdasarkan hasil analisis menggunakan skala likert, maka dapat diketahui bahwa angka indeks persepsi masyarakat terhadap dampak sosial ekonomi dari perusahaan perkebunan kelapa sawit PT. Henrison Inti Persada berada pada titik $81,11 \%$ dan tergolong tinggi, artinya keberadaan perusahaan perkebunan kelapa sawit PT. Henrison Inti Persada memiliki dampak sosial dan ekonomi yang harus di tingkatkan lagi kepada masyarakat, karena setiap indikator ada dampak positif dan juga dampak negatif yang harus di lihat oleh perusahaan perkebunan kelapa sawit PT. Henrison Inti Persada.

Dengan Interpretasi Nilai :

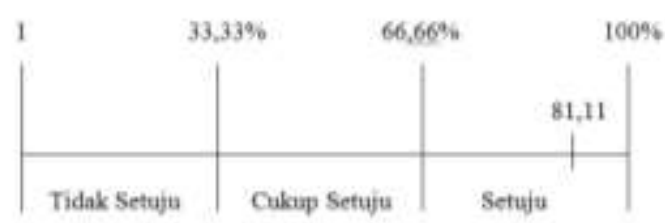




\section{KESIMPULAN DAN SARAN}

\begin{abstract}
Kesimpulan
Dampak sosial ekonomi dari perusahaan perkebunan kelapa sawit PT. Henrison Inti Persada mempengaruhi persepsi masyarakat di kampung Malalilis, Gisim Darat dan Maladofok, Kabupaten Sorong Papua Barat. Perusahaan perkebunan kelapa sawit memiliki dampak positif dan dampak negatif. Dampak positif yang ditimbulkan antara lain adalah meningkatkan pendapatan masyarakat, memperluas lapangan pekerjaan, adanya sarana sosial seperti (tempat ibadah, sekolah dan puskesmas). Selain dampak positif ternyata juga memberikan dampak negatif antara lain, masyarakat lokal merasa hilangnya nilai-nilai sosial yang sudah ada sejak turun temurun, pendatang memiliki kesempatan dan peluang yang lebih besar untuk bekerja di perusahaan sehingga masyarakat lokal memiliki peluang yang kecil untuk bekerja di perusahaan.
\end{abstract}

\section{Saran}

Saran dari penelitian ini adalah :

1. Perusahaan perkebunan kelapa sawit PT. Henrison Inti Persada Kabupaten Sorong Papua Barat perlu memperhatikan aspek sosial masyarakat, dalam hal ini, kehadiran pendatang akibat adanya perusahaan merupakan hal yang menganggu kehidupan sosial masyarakat, sehingga pendatang memiliki kesempatan dan peluang yang lebih besar untuk bekerja di perusahaan. Dan juga perusahaan perlu meningkatkan aspek ekonomi masyarakat, dalam hal ini, Peluang usaha yang terbuka semenjak kehadiran perusahaan merupakan hal yang positif bagi masyarakat, memperbanyak tenaga kerja lokal, memperhatikan kebutuhan masyarakat dengan cara meningkatkan perekonomian masyarakat.

2. Bagi kalangan akademisi diharapkan penelitian ini dapat dijadikan referensi untuk penelitian-penelitian yang terkait dengan persepsi masyarakat terhadap dampak sosial ekonomi.

\section{DAFTAR PUSTAKA}

Ambadar, Jackie. 2008. CSR dalam Praktik di Indonesia. Jakarta: PT. Elex Media Komputindo.

Effendi, Unong Uchjana. 2000. Ilmu Komunikasi, Teori dan Praktek.Bandung: PT. Remaja Rosdakarya.

.2001. Dimensi Komunikasi. Bandung: PT. Remaja Rosdakarya.

H. Kaelan. 2005. Metode Penelitiaan Kualitatif Interdisipineer Bidang Sosial, Budaya, Filsafat, Seni dan Humaniora .Yogyakarta: Paradigma.

Hadi, Agus Purbathin. 2001. Hubungan Antara Komunikasi Publik Perusahaan dan Sikap Komunitas Setempat (Kasus Perusahaan Pertambangan di Nusa Tenggara Barat). Tesis. Program Pasca Sarjana. Institut Pertanian Bogor.

Herlin, Fauzia. 2008. Analisis Tanggung Jawab Sosial Perusahaan (Corporate Social Responsibility/ CSR) sebagai Upaya Pengembangan Masyarakat (Studi Kasus Pengembangan Perekonomian Lokal Melalui Program Kemitraan PT. ANTAM Tbk di Tanjung Barat, Jakarta). Skripsi. Program Studi Komunikasi dan Pengembangan Masyarakat. Institut Pertanian Bogor.

. 2012. Persepsi ; Pengertian, Definisi dan Faktor yang Mempengaruhi. http://www.duniapsikologi.com/perseps i-pengertian-definisi-dan-faktor-yangmempengaruhi/. Diakses 2 Juni 2016.

2011. Jenis-Jenis Persepsi, Dinamika Persepsi, Prinsip-Prinsip \& Determinasi Persepsi. http:// www. Psychologymania .com /2011/09/ jenis jenis-persepsi-dinamika -persepsi .html. Diakses 2 Juni 2016. 
Kalaen. 2005. Metode Penelitian Kualitatif Interdisipliner Bidang Sosial, Budaya, Filsafat, Agama dan Hukum. Penerbit: Paradigma, Yogyakarta.

Kriyantono, Rachmat. 2006. "Teknik Praktis Riset Komunikasi: Disertai Contoh Praktis Riset Media, Public Relation, Advertising, Komunikasi Organisasi, Komunikasi Pemasaran." Jakarta: Kencana.

Leavitt, Harold J. 1978. "Psikologi manajemen." Jakarta (ID): Erlangga.

Mulyana, Deddy. 2000. Ilmu Komunikasi Suatu Pengantar. Remaja Rosdakarya Bandung.

Rakhmat, Jalaludin. 2005. Psikologi Komunikasi. Remaja Rosdakarya Bandung.

Rakhmat, Jalaluddin. 2004. Metode Penelitian Komunikasi Dilengkapi Contoh Analisis Statistik. Remaja Rosdakarya Bandung.
Restiyanti, Prasetijo dan John J.O.I Ihwalauw. 2005. Perilaku Konsumen. Penerbit ANDI Yogyakarta.

Rusmawardi, Rusmawardi. 2007. Dampak Berdirinya Perkebunan Kelapa Sawit (Elaeis guineensis jack) Terhadap Kondisi Sosial Ekonomi Masyarakat (Studi Kasus Pada Desa Kabuau, Kecamatan Parenggean, Kabupaten Kotawaringin Timur, Propinsi Kalimantan Tengah). Diss. University of Muhammadiyah Malang. eprints.umm.ac.id. Diakses 20 Juni 2016.

Sujarweni, V. W. 2014. Metodologi Penelitian. Penerbit: Pustaka Baru Press. Yogyakarta.

Syamsuddin, 2011. Dampak Berdirinya Perusahaan Kelapa Sawit (PT. Damai Jaya Lestari) Terhadap Kondisi Sosial Ekonomi Masyarakat. Skripsi.

Umboh, Jennifer, 2014. Pengaruh Perubahan Sosial Terhadap Lahan Tidur di Desa Tombasian Atas Kecamatan Kawangkoan Barat. Skripsi Universitas Sam Ratulangi, Manado. 